\title{
PENGARUH LITERASI TERHADAP PERKEMBANGAN PEMBELAJARAN PKN
}

\author{
Agrisa Alya Fayza ${ }^{\bowtie}$, Dadi Mulyadi Nugraha, Supriyono.
}

Indonesian Education University

\begin{abstract}
Info Artikel
Abstrak

Sejarah Artikel:

Disubmit: April 2021

Direvisi: Mei 2021

Diterima: Mei 2021

Penelitian ini dilatarbelakangi oleh rendahnya pemahaman belajar Pendidikan Kewarganegaraan atau PKN dan rendahnya pengaruh literasi terhadap pembelajaran di sekolah ataupun di perguruan tinggi. Para pelajar dan mahasiswa masih rendah dalam

Keywords:

Literacy; Learning; Civic

Education. memahami apa itu pengertian literasi dan bagaimana kegiatan literasi serta apa pengaruh literasi terhadap pembelajaran di sekolah atau di perguruan tinggi. Dari hasil penelitian ini ditemukan bahwa literasi memiliki pengaruh yang sangat besar terhadap pembelajaran di sekolah maupun di perguruan tinggi khususnya dalam mata pelajaran Pendidikan Kewarganegaraan atau PKN, Sebagian besar para pelajar dan mahasiswa pun sudah sadar dan mengetahui pengaruh besar dari kegiatan literasi tersebut, dan sudah banyak beberapa dari mereka yang mengimplementasikannya dalam pembelajaran di sekolah ataupun di perguruan tinggi.
\end{abstract}

\begin{abstract}
This research is motivated by the low understanding of learning Citizenship Education or PKN and the low influence of literacy on learning at school or college. Students and students are still low in understanding what literacy is and how literacy activities are and what literacy affects learning at school or in college. From the results of this study, it was found that literacy has a very large influence on learning atschool and in college, especially in the subject of Citizenship Education or Civics. Most of the students are aware of and know the big influence of these literacy activities, and there have been many. some of them implement it in learning at school or in college.
\end{abstract}

(C) 2021 Universitas Negeri Semarang

\Alamat korespondensi:

Universitas Pendidikan Indonesia, J1. Dr. Setiabudi No. 229, Kec.

Sukasari, Bandung, 40154

ISSN 2252-7133

E-mail: agrisaalyafayza@upi.edu 


\section{PENDAHULUAN}

Kualitas pendidikan merupakan cerminan dari sebuah mutu sumber daya manusia yang berada di suatu daerah, karena dengan memiliki pendidikan masyarakat akan dapat mampi mengatasi sebuah permasahan hidup dengan menggunakan pengetahuan hasil dari pendidikan yang sudah dimiliki. Oleh karena pendidikan adalah sebuah faktor terbesar dari rendahnya kualitas sumber daya masyarakat. Menurut Suastra (2009) mengatakan bahwa pendidikan era ini bersandar pada 4 pilar, yaitu: 1) learning to know, yaitu peserta didik yang mempelajari suatu hal agar dapat mendapat pengetahuan. 2) learning to do, yaitu seorang peserta didik belajar menggunakan pengetahuan yang telah dimiliki untuk mengembangkan sebuah keterampilan. 3) learning to be, yaitu seorang peserta didik belajar menggunakan suatu pengetahuan dan keterampilan untuk menemukan jati dirinya. 4) learning to live together, yaitu peserta didik yang belajar untuk menyadari adanya keterkaitan ketergantungan antar sesama sehinnga dapat menghargai antar sesama manusia.

Berdasarkan hal tersebut kualitas pendidikan harus ditingkatkan lagi dari jenjang sekolah dasar sampai jenjang perguruan tinggi dengan menggunakan sasaran pencapaian pendidikan yang telah di rangkum dalam bentuk sistem yang terkhusus sehingga pelaku pendidikan mempunyai tujuan secara tepat dan terperinci. Hal tersebut tercantum dalam Pasal 3 Undang-Undang Republik Indonesia nomor 20 tahun 2003 yang menyatakan dengan tegas bahwa : Pendidikan nasional berfungsi untuk mengembangkan kemampuan dan untuk membentuk watak serta peradaban bangsa yang bermartabat dalam rangka mencerdaskan kehidupan bangsa, yang memiliki tujuan untuk perkembangan sebuah potensi seorang peserta didik agar bisa menjadi manusia yang beriman serta bertaqwa kepada Tuhan Yang Maha Esa, berakhlak mulia, cakap, sehat, berilmu, kreatif, mandiri dan menjadi warga negara yang demokratis serta bertanggung jawab.

Dengan tujuan tersebut pendidikan menurut Barnawi dan Arifin (2016) terdapat 2 hal yang sangat penting untuk diwujudkan oleh lembaga atau instansi pendidikan dalam negeri, yaitu: 1) pengembangan kemampuan peserta didik. 2) membentuk watak.
Pendidikan adalah sebuah sarana yang berposisi sentral untuk mewujudkan sumber daya manusia yang berkualitas dan yang berdaya saing tinggi sehingga memperoleh pengetahuan sehingga dapat mengubah sikap dan juga pendidikan berperan sangat penting untuk mengembangkan kemampuan atau keterampilan seseorang. Sehingga untuk mendapatkan pengetahuan dalam pengembangan sikap ataupun mengembangkan kemampuan tersebut, seseorang harus belajar. Menurut Crow (dalam Ihsan, 2005) menyebutkan bahwa pendidikan merupakan sebuah proses yang berisi tentang berbagai macam kegiatan yang dianggap cocok bagi seorang individu. Kemudian Driyarkara (dalam Ihsan, 2005) menyebutkan juga bahwa pendidikan merupakan upaya dalam memanusiakan manusia muda. Pendidikan dapat dikatakan berhasil dan berkualitas apabila terjadi penyeleggaraan proses pendidikan yang efektif dan juga efisien dengan melibatkan semua komponen-komponen pembelajaran.

Sebuah upaya untuk menghasilkan lulusan yang berkualitas diperlukan perubahanperubahan yang mendasar dalam proses pembelajaran di dalam instansi pendidikan dengan proses pembelajarannya diperbaiki dengan meningkatkan kinerja guru ditambah dengan upaya meningkatkan budaya membaca peserta didik dalam proses pembelajaran.

Akan tetapi dalam pelaksanaan kegiatan belajar mengajar pada instansi pendidikan dirasa kurang efisien, seperti yang dikemukakan Pitman dan Daniels (2016) menunjukan bahwa seorang guru belum bisa maksimal dalam melaksanakan proses pembelajaran dalam mengaplikasikan berbagai macam model pembelajaran yang diterapkan di dalam sebuah kelas. Seorang guru lebih cenderung menggunakan metode pembelajaran satu arah atau disebut dengan teacher centered. Dalam sebuah pembelajaran yang memiliki sifat teacher centered ini dirasa sulit untuk bisa mengembangkan keaktifan siswa dalam proses pembelajaran. Sehingga kemampuan literasi seorang siswa cenderung tidak bisa maksimal. Dalam penelitiannya Pitman dan Daniels (2016) melakukan survei kemampuan literasi pada SMA Negeri 7 Surakarta yakni komponen Knowledge memiliki nilai rata-rata 60 , attitude 60 dan concern 69. Hasil tersebut menunjukan kemampuan literasi siswa masih dalam kategori kurang.

Hal tersebut diperkuat dengan sebuah hasil observasi yang dilakukan oleh Ni Kadek 
Arsani dkk (2017) yang menyebutkan bahwa pembelajaran peserta didik di dalam kelas, yaitu : 1) siswa tidak bersemangat dan mengantuk dalam mengikuti proses pembelajaran 2) interaksi sebagian besar terjadi hanya pada pendidik dengan peserta didik 3) pada saat pendidik menjelaskan pelajaran banyak siswa yang mengobrol dan tidak memperhatikan 4) sebagian besar peserta didik pasif dalam melakukan pembelajaran 5) pendidik tidak berinovasi dalam melakukan proses pembelajaran 6) metode pembelajaran yang dilaksanakan hanya menggunakan metode teacher center 7) peserta didik tidak mengerti dengan apa yang sedang di terangkan oleh pendidik. Oleh karena itu berdasarkan hal tersebut budaya literasi sangat diperlukan untuk tercapainya proses pembelajaran yang efisien dan efektif dan juga untuk merealisasikan tujuan pendidikan yang termaktub pada Pasal 3 Undang-undang Republik Indonesia nomor 20 tahun 2003.

\section{Literasi Dikalangan Pelajar dan Mahasiswa}

Literasi dapat diartikan sama dengan melek huruf, kecakapan dalam membaca dan menulis serta kemampuan baca dan tulis. Dimana sebuah kemampuan membaca dan menulis dapat berkembang menjadi sebuah kemampuan yang terdiri dari kemampuan membaca, menulis, berbicara, menyimak dan memanfaatkan teknologi. Tuntutan akan suatu pengetahuan yang lebih mendalam mengenai pendidikan di Indonesia sekarang, dapat menambah luas pengertian dari literasi.

Pengertian dari literasi dari zaman ke zaman berubah sesuai dengan kebutuhan dan konteksnya, awalnya pengertian literasi sangat sempit hanya sebatas kemampuan membaca dan menulis, tetapi saat ini pengertian literasi berkembang sangat pesat dan meluas menjadi sebuah kemampuan dalam membaca, menulis, menyimak serta memaanfaatkan teknlogi. Hal ini terjadi karena di era digitalisasi saat ini semua kegiatan selalu identik serta berhubungan secara langsung dengan teknologi, oleh karena itu kemampuan literasi pun berkembang mengikuti era globalisasi. Sehingga literasi adalah kemampuan membaca, berbicara, menulis, menyimak serta memanfaatkan teknologi. Karena itu literasi bisa berperan sangat penting dalam perkembangan era globalisasi saat ini, agar seseorang bisa mengembangkan dirinya dalam bidang sosial, ekonomi dan budaya dari proses pembelajaran literasi. Tanpa adanya kemampuan literasi maka seseorang tidak akan dapat berkembang dengan baik serta akan lebih merasa kesulitan karena keterbatasan yang ia miliki yang berhubungan dengan kemampuan literasi. Orang yang dapat berkembang dengan baik di tengah-tengah arus globalisasi adalah orang-orang yang mempunyai kemampuan literasi yang sangat baik karena ia bisa menyesuaikan dirinya serta bisa memahami dunia lebih baik daripada orang yang buta akan literasi.

Saat ini Indonesia sedang berada dalam keadaan yang sangat darurat literasi. Seseorang yang memiliki kemampuan literasi rendah dikhawatirkan dapat berdampak buruk pada penurunan kualitas hidup, sosial, bahkan ekonomi. Dampak lain yang bisa timbulkan dari rendahnya kemampuan literasi masyarakat adalah rendahnya sebuah kualitas diri, karena pada dasarnya kemampuan literasi turut mempengaruhi bentuk etika dan moral seseorang. Ketika seseorang memiliki kemampuan literasi yang rendah maka orang tersebut akan memiliki pengetahuan yang sangat sedikit, moral yang tidak sesuai hingga beberapa penyimpangan sosial yang terjadi disebabkan oleh rendahnya tingkat literasi pada masyarakat. Hal tersebut akan mempengaruhi kualitas dirinya, ia akan banyak sekali tertinggal informasi baik tentang sosial, budaya, politik, dan lain sebagainya termasuk teknologi. Adanya kasus tersebut akan membuat sebuah negara berkurang kualitasnya serta negara tersebut akan lebih muda dikuasai oleh bangsa asing.

Dalam kegiatan literasi banyak sekali hal yang bisa didapatkan ketika seseorang melakukan kegiatan literasi. Manfaat yang didapatkan adalah berupa bertambahnya perbendaharaan kosa kata seseorang, bertambahnya wawasan serta informasi baru, meningkatkan interpersonal seseorang, mengoptimalkan kinerja untuk melakukan kegiatan membaca sera menulis, akan lebih mudah dalam memaknai atau memahami suatu informasi, meningkatkan kemampuan verbal seseorang, meningkatkan kefokusan serta konsentrasi seseorang, meningkatnya kemampuan berpikir sesorang dalam menganalisa sesuatu, dan bisa meningkatkan kemampuan seseorang dalam menulis atau merangkai sebuah kata.

Kegiatan literasi dalam pembelajaran di sekolah maupun kampus sudah menjadi hal yang sangat lumrah dan sering dilakukan oleh para 
siswa ataupun mahasiswa. Kegiatan literasi ini bisa memuat kegiatan berupa membaca sebuah majalah, koran, artikel, jurnal, buku, ataupun referensi yang lainnya. Kegiatan literasi juga bisa terkait dengan kegiatan memahami teknologi agar para siswa dan mahasiswa bisa melek terhadap teknologi. Kegiatan literasi dilakukan untuk menunjang kegiatan pembelajaran di sekolah ataupun di kampus, karena dengan adanya kegiatan literasi ini maka para siswa akan lebih mudah dalam memahami penyampaian materi yang disampaikan oleh guru ataupun dosennya, sehingga para siswa atau mahasiswa sudah memiliki skemata. Skemata ini merupakan sebuah pengetahuan serta pengalaman yang dimiliki oleh seseorang. Jadi, ketika semakin sering seseorang melakukan kegiatan membaca, maka semakin besar juga peluang untuk memperoleh skemata tersebut dan juga semakin maju jugalah tingkat pendidikannya. Hal inilah yang mendasari banyak sekali orang yang berargumen bahwa membaca sama dengan membuka jendela dunia.

Pendidikan yang sangat berkualitas menjadi sebuah kebutuhan yang amat penting di era persaingan dunia yang kian kompetitif. Untuk menjadikan sebuah dunia pendidikan yang berkualitas, tentu banyak sekali faktor yang berhubungan serta saling memengaruhi. Salah satu upaya dari pemerintah yang menjadikan pendidikan di Indonesia terbilang berkualitas adalah melalui program yang mengingkatkan budaya literasi (membaca dan menulis). Pemerintah menyadari bahwa Pendidikan karakter sangat dibutuhkan bagi peserta didik, sehingga diciptakannyalah sebuah kebijakan membaca buku selama 15 menit sebelum pembelajaran dimulai. Kegiatan ini membutuhkan suatu pembiasaan yang harus terus menerus dilakukan dari sejak usia dini serta konsistensinya pun sangat diperlukan. Ada banyak sekali kegiatan yang merujuk pada pembiasaan gerakan literasi di sekolah, yang paling penting adalah harus ada kemauan dari semua warga sekolah untuk bisa mensukseskan program tersebut. Ada berbagai cara yang bisa dilakukan untuk mendekatkan buku sedekat mungkin dengan anak anak, yani diantaranya adalah diberikan kemudahan untuk mengakses buku, seperti website atau blog buku, ataupun dengan dibuatnya sebuah taman literasi. Hal tersebut tidak akan pernah terlepas dari dukungan kepala sekolah, guru, serta seluruh warga sekolah. Selain itu, dalam menyukseskan program ini juga tentu harus ada keteladanan dari semua pihak sekolah. Bahkan akan lebih baik lagi jika budaya literasi dibawa ke dalam keluarga, terutama ayah dan ibu yang harus ikut serta untuk mendukung. Budaya literasi ini tidak hanya menganjurkan membaca literatur yang berat, tetapi pilihlah bacaan yang di sukai anak anak. Seperti membaca buku cerita anak, cerita legenda atau pilihan yang lainnya yang sesuai dengan umurnya. Dengan begitu semua kalangan masyarakat akan mencintai budaya membaca. Budaya literasi akan lebih meningkatkan inovasi belajar.

\section{Literasi Dalam Pembelajaran Pendidikan Kewarganegaraan}

Kegiatan literasi di sekolah ataupun di perguruan tinggi bisa dilakukan sebagai sarana pembelajaran untuk mencapai tujuan pembelajaran yang baik dan benar. Kegiatan literasi bagian dari upaya pembelajaran yang berpusat kepada peserta didik atau mahasiswa, sehingga akan tercipta pembelajaran yang terlaksana secara efektif (Maftuhin et al., 2021). Seringkali literasi dilakukan tetapi setiap orang tidak memahami manfaat serta pengaruhnya terhadap aspek lain, padahal kegiatan literasi ini memiliki seribu manfaat bagi pelakunya serta kegiatan literasi juga memberikan pengaruh besar terutama dalam pembelajaran Pendidikan Kewarganegaraan atau PKN.

Membaca sebuah referensi mengenai pendidikan kewarganegaraan dapat menambah serta memperkuat pengetahuan kita terkait dengan pembelajaran Pendidikan Kewarganegaraan atau PKN. Maka tak jarang sekali para guru atau dosen selalu menyarankan siswanya atau mahasiswanya untuk membaca beberapa literatur bahkan banyak literatur, hal tersebut berguna sebagai sebuah penunjang pembelajaran serta agar para peserta didik serta mahasiswa bisa lebih paham terkait dengan keadaan bangsanya sendiri.

Membaca padahal tidak berfungsi untuk menambah informasi, tetapi juga lebih dari itu, yakni membaca juga bisa berpengaruh terhadap sikap personal, moral, dan kecerdasan seseorang. Membaca bisa meningkatkan keterampilan yang lainnya, terkhusus kecerdasan yang berkaitan dengan ilmu kewarganegaraan, karakter bangsa, serta budi pekerti. Karena jika dilihat negaranegara yang memiliki budaya membaca yang terbilang sangat tinggi, biasanya terbukti bahwa warga negara tersebut menjadi warga negara yang sangat cerdas. 
Penelitian ini dilakukan untuk mengetahui sejauh mana para peserta didik atau mahasiswa mengenal jauh tentang kegiatan literasi sebagai penunjang pembelajaran di sekolah atau kampus, apakah kegiatan literasi yang dilakukan sudah efektif sesuai dengan ketentuan atau tidak, dan apakah para peserta didik atau mahasiswa menyadari akan pentingnya kegiatan literasi tersebut, karena dari hasil penelitian terungkap bahwa kegiatan literasi ini memiliki banyak sekali manfaat terutama bagi pembelajaran di sekolah ataupun di kampus.

\section{METODE}

Penelitian ini menggunakan metode kuantitatif, penelitian dilakukan secara online melalui sebuah platform digital. Pengambilan data menggunakan angket yang disebar kebeberapa pelajar serta mahasiswa. Fokus penelitian ini adalah bagaimana pengaruh literasi terhadap keefektivitasan pembelajaran di sekolah serta di perguruan tinggi terkhusus dalam pembelajaran Pendidikan Kewarganegaraan atau PKN.

\section{PEMB AHASAN}

Dalam era globalisasi sekarang ini, tiap-tiap warga Negara termasuk juga seorang peserta didik dituntut agar mempunyai beberapa keterampilan yang sangat diperlukan di dalam kehidupan seperti saat ini yang bukan hanya sekadar menjadi warga negara, tetapi juga sebagai warga dunia, oleh karena itu kehidupan seorang peserta didik bisa lebih fungsional dan lebih bermakna. Metiri Group (2009) menyebutkan ada beberapa keterampilan yang harus dikuasai yakni meliputi: (1) kemampuan literasi di zaman digital; (2) berpikir secara inventif untukmodal intelektual; (3) komunikasi secara interaktif untuk mengasah keterampilan sosial dan personal; dan (4) hasilhasil yang berkualitas dan terkini.

Sebuah keterampilan membaca bagi seseorang sangat berperan penting dalam kehidupannya karena sebuah pengetahuan dapat diperoleh melalui kegiatan membaca. Oleh karena itu, sebuah keterampilan membaca ini harus dikuasai oleh setiap peserta didik dan mahasiswa dengan baik sedari dini. Sebuah Gerakan Literasi Sekolah dapat mendukung gerakan penumbuhan budi pekerti yang sebagaimana tertuang dalam sebuah Peraturan Menteri Pendidikan dan Kebudayaan Nomor 13
Tahun 2015. Disebutkan bahwa salah satu kegiatan yang ada dalam Gerakan tersebut merupakan "kegiatan 15 menit untuk membaca buku yang bukan pelajaran (nonpelajaran) sebelum waktu pembelajaran dimulai". Kegiatan tersebut dilaksanakan agar bisa meningkatkan minat baca peserta didik serta sekaligus meningkatkan keterampilan membaca agar pengetahuan bisa dikuasai dengan lebih baik. Materi bacaan berisi tentang sebuah nilai-nilai budi pekerti, berupa sebuah kearifan lokal, hal yang berkaitan dengan nasional, serta global yang disampaikan sesuai tahap perkembangan peserta didik (Dirjen Dikdasmen, 2016).

Sebuah pembelajaran literasi di sekolah dilakukan untuk mencapai tujuan-tujuan tertentu. Pada awalnya, sebuah pembelajaran literasi di lingkungan sekolah hanya diperuntukkan agar para siswa terampil dalam menguasai dimensi ilmu pendidikan, yakni dapat menguasai materi yang mencakup tentang fonem, morfem, grafofonemik, morfofonemik, dan sintaksis. Dalam perkembangannya, kegiatan literasi ditunjukkan agar para siswa dapat menguasai sebuah dimensi kognitif dari literasi yang mencakup proses pemahaman, proses menulis, konsep analisis, serta wacana tertulis.

Berbagai macam literatur yang dapat dibaca adalah bisa berupa sebuah koran, majalah, novel, ataupun buku yang terkait dengan pembelajaran di sekolah ataupun di kampus. Hal tersebut menunjukan bahwa generasi zaman sekarang masih gemar ataupun suka membaca berbagai macam literatur yang berkaitan dengan informasi kewarganegaraan ataupun kenegaraan, maka hal ini bisa berhubungan erat terhadap pengembangan pembelajaran Pendidikan kewarganegaraan (PKN) di sekolah ataupun di kampus. Dengan membaca literatur tersebut maka seorang siswa ataupun mahasiswa akan terfasilitasi dengan baik pengetahuannya dan dapat memahami materi secara penuh karena sudah membaca berbagai literatur yang berkaitan dengan pembelajaran Pendidikan Kewarganegaraan (PKN).

Berdasarkan analisis data dapat diperoleh hasil bahwa literasi memberikan pengaruh positif terhadap efektivitas belajar siswa, terutama dalam pembelajaran pendidikan kewarganegaraan. Adanya sebuah kegiatan literasi bisa mendorong siswa untuk meningkatkan pengetahuannya agar bisa 
mencapai tujuan belajar. Seperti pendapat yang dikemukakan Septiyantono (2016: 1.16), "Literasi adalah kunci utama dalam peningkatan pengetahuan seorang siswa". Bahwa dengan literasi, seorang siswa akan mampu belajar secara mandiri juga literasi berpengaruh terhadap efektivitas belajar siswa. Jadi salah satu upaya yang bisa dilakukan untuk meningkatkan efektivitas belajar siswa yang baik adalah dengan siswa harus melakukan kegiatan literasi yang baik pada dirinya sendiri.

Dalam penelitian yang dilakukan melalui penyebaran angket kepada para generasi milenial dan generasi $\mathrm{Z}$ ditemukan 74 responden terdiri dari Sebagian kecil siswa SMP dan SMA, serta didominasi oleh para mahasiswa. Penelitian dilakukan untuk mengetahui seberapa banyak siswa dan mahasiswa yang memiliki kegemaran dalam membaca. Hasil penelitian menunjukkan sebagai berikut:

Tabel 1. Kegemaran membaca responden

\begin{tabular}{cc}
\hline Keterangan & Persentase \\
\hline Gemar & $27 \%$ \\
Terkadang & $70,3 \%$ \\
Tidak gemar & $4,1 \%$ \\
\hline
\end{tabular}

Sumber: penelitian 2021

$\begin{array}{rlr}\text { Dari } & \text { hasil } & \text { penelitian tersebut } \\ \text { menunjukkan } & \text { bahwa } & \text { diantaranya } \\ 27 \%\end{array}$ menyatakan bahwa dirinya gemar membaca, $70,3 \%$ menyatakan bahwa dirinya terkadang gemar membaca, dan 4,1\% menyatakan bahwa dirinya tidak gemar membaca. Dilihat dari hasil persentase tersebut bisa disimpulkan bahwa generasi saat ini dalam hal literasi terbilang masih sangat rendah, dilihat dari persentase tersebut masih banyak orang yang menyatakan bahwa dirinya terkadang gemar membaca dan tidak menyataka bahwa dirinya gemar membaca. Hal tersebut terjadi dikarenakan beberapa hal, yakni bisa terjadi karena lingkungan keluarga yang tidak mendukung atau di rumah tidak dibiasakan membaca oleh orang tuanya, adanya teknologi yang semakin canggih pun membuat seseorang semakin malas membaca karena banyak hal yang bisa dibuat lebih instan, lingkungan sekolah yang kurang merangsang para peserta didiknya untuk bisa memiliki kegemaran membaca serta mengelola informasi, kurangnya motivasi bisa menjadi alasan seseorang tidak gemar dalam membaca, dan kemungkinan yang terakhir adalah kurangnya atau minimnya fasilitas yang menunjang kita untuk melakukan kegiatan membaca, bisa dari referensi bacaan yang kurang ataupun tidak adanya tempat yang nyaman yang bisa digunakan untuk membaca.

Kegemaran membaca para peserta didik sudah terbilang cukup baik, tetapi jika dikaitkan dengan bacaan mengenai Pendidikan Kewarganegaraan maka akan lain kegemarannya, hal tersebut terbukti dalam sebuah survei yang dilakukan.

Tabel 2. Ketertarikan literatur PKN

\begin{tabular}{cc}
\hline Keterangan & Persentase \\
\hline Sangat tertarik & $9,5 \%$ \\
Tertarik & $43,2 \%$ \\
Sedikit tertarik & $44,6 \%$ \\
Tidak tertarik & $4,1 \%$ \\
\hline
\end{tabular}

Sumber: penelitian 2021

Dari hasil penelitian tersebut jelas menunjukan bahwa para peserta didik didominasi dengan orang-orang yang tidak terlalu tertarik dengan literatur yang berkaitan dengan Pendidikan Kewarganegaraan atau PKN, dan hanya sedikit sekali peserta didik yang menyatakan sangat amat tertarik. Oleh karena itu tergambarkan jelas bahwa kebanyakan para peserta didik tidak ingin tahu banyak tentang bagaimana keadaan negaranya sendiri dan bisa terbilang urgensi terhadap kecintaan tanah air pun tidak begitu banyak, masih banyak para peserta didik yang tidak memperdulikan hal tersebut. Oleh karena itu, pentingnya edukasi kepada para peserta didik agar bisa lebih paham akan manfaat yang didapatkan ketika kita membaca sebuah literatur tentang Pendidikan Kewarganegaraan, selain kita bisa menjadi warga negara yang baik, kita juga akan menjadi semakin cinta kepada negara kita sendiri, yakni negara Indonesia.

Hasil penelitian menunjukan seberapa banyak peserta didik serta mahasiswa yang membaca literatur mengenai pembelajaran Pendidikan Kewarganegaraan atau PKN, hasil penelitian menunjukan sebagai berikut:

Tabel 3. Responden membaca literatur PKN

\begin{tabular}{cc}
\hline Keterangan & Persentase \\
\hline Tidak membaca & $10,8 \%$ \\
Mungkin membaca & $20,6 \%$ \\
Pernah membaca & $68,9 \%$ \\
\hline
\end{tabular}

Sumber: penelitian 2021

Dari hasil tersebut, dapat ditarik kesimpulan bahwa banyak responden yang 
tertarik dengan literatur mengenai Pendidikan kewarganegaraan dan hanya sedikit responden yang menyatakan dirinya tidak tertarik terhadap literatur yang berkaitan dengan Pendidikan kewarganegaraan, hasil persentase juga menunjukan bahwa $10,8 \%$ diantaranya tidak pernah membaca literatur yang berkaitan dengan informasi kewarganegaraan ataupun kenegaraan, 20,6\% menyatakan bahwa dirinya mungkin pernah membaca literatur yang berkaitan dengan informasi kewarganegaraan ataupun kenegaraan, dan $68,9 \%$ menyatakan bahwa dirinya pernah membaca literatur yang berkaitan dengan informasi kewarganegaraan ataupun kenegaraan. Berarti artinya menunjukan masih banyak siswa dan mahasiswa yang membaca literatur yang terkait dengan pembelajaran Pendidikan Kewarganegaraan atau PKN, baik kegiatan literasi tersebut disengaja atau tidak sengaja dan dipaksa ataupun tanpa paksaan, karena terkadang seorang guru atau dosen akan memaksa siswanya atau mahasiswanya untuk membacasebuah literatur yang terkait dengan pembelajaran sebagai bahan ajar para peserta didiknya.

Berikut adalah data yang menunjukan kefektifan kegiatan literasi sebagai penunjang pembelajaran Pendidikan Kewarganegaraan atau PKN.

Tabel 4. Efektivitas literasi pada pembelajaran PKN

\begin{tabular}{cc}
\hline Keterangan & Persentase \\
\hline Efektif & $95,9 \%$ \\
Tidak efektif & $8,1 \%$
\end{tabular}

Sumber: penelitian 2021

Data pada tabel 4 menunjukan bahwa kegiatan literasi memberikan dampak yang begitu besar terhadap keefektifan pembelajaran di sekolah maupun di kampus. Beberapa orang menyatakan kegiatan literasi efektif karena dengan adanya kegiatan membaca maka para siswa atau mahasiswa akan dapat lebih mudah mencerna atau memahami suatu teori, juga dengan adanya kegiatan literasi ini akan membuka celah besar para siswa atau mahasiswa menuju gerbang kesuksesan dalam pembelajaran. Berbeda dengan orang yang mengatakan bahwa kegiatanliterasi tidak efektif bagi pembelajaran Pendidikan Kewarganegaraan karena pembelajaran PKN ini lebih menitikberatkan pada aspek pembelajaran observasi langsung ke lapangan agar para siswa atau mahasiswa dapat lebih paham dan memahami secara spesifik apa yang terjadi di lapangan, karena teori saja dianggap tidak cukup untuk menunjang efektivitas pembelajaran.

Dari semua hasil penelitian tersebut dapat disimpulkan bahwa kegiata literasi ini sangat berpengaruh terhadap pembelajaran di sekolah ataupun di kampus. Dengan banyaknya tingkat melek huruf serta tingginya minat membaca para siswa serta mahasiswa maka memungkinkan kegiatan literasi ini efektif untuk dilakukan dalam kegiatan pembelajaran ataupun nonpembelajaran. Sebagian besar para siswa dan mahasiswa sudah menyadari akan pentingnya kegiatan literasi untuk menunjang pembelajaran di dalam kelas, karena kegiatan literasi yang memiliki banyak sekali manfaat salah satunya adalah dapat meningkatkan prestasi belajar siswa atau mahasiswa di dalam kelas. Karena dengan adanya sebuah kegiatan literasi maka akan menambah pengetahuan ataupun wawasan seseorang.

Penunjang literasi dalam pembelajaran Pendidikan Kewarganegaraan adalah dengan adanya sebuah pemahaman yang dimiliki oleh seorang siswa dan mahasiswa terhadap ilmu kenegaraan, sehingga akan terciptanya sebuah generasi muda yang gemilang, cemerlang yang bisa membawa negerinya menjadi sebuah negara yang terdepan serta maju. Untuk mengefektifkan literasi pada pembelajaran PKN perlu adanya sebuah inovasi menggunakan aplikasi civication (Civic Application), karena dengan adanya literasi maka akan meningkatkan civic competence (kompetensi kewarganegaraan) dan bisa mengembangkan literasi digital (Rifai et al., 2021). Apalagi para pemuda saat ini adalah seorang agen perubahan atau yang dikenal dengan Agent of Change maka akan sangat mudah untuk para pemuda berkualis ini memberikan kontribusi yang sangat besar dan baik dari hasil implementasi pembelajaran Pendidikan Kewarganegaraan (PKN).

\section{SIMPULAN}

Berdasarkan hasil dari analisis pembahasan hasil penelitian, bisa ditarik sebuah kesimpulan bahwa terdapat pengaruh positif serta signifikan dari literasi terhadap kefektivitasan belajar siswa dan mahasiswa terutama mata pelajaran ataupun mata kuliah Pendidikan kewarganegaraan, dan budaya membaca juga telah memberikan pengaruh 
terhadap yang besar terhadap perkembangan kompetensis kecerdasan kewarganegaraan siswa. $\mathrm{Hal}$ ini dapat dilihat atas perkembangan kompetensi kecerdasan kewarganegaraan, yang terdiri dari aspek kecerdasan intelektual, kecerdasan emosional, dan kecerdasan moral siswa. Dengan adanya kegiatan literasi maka akan memberika hasil yang maksimal terhadap pembelajaran Pendidikan Kewarganegaraan di sekolah ataupun di kampus. Kegiatan literasi mengenai Pendidikan Kewarganegaraan akan menghasilkan seorang individu yang berkualitas, yang cerdas serta individu yang rasa cinta kebangsaannya sangat tinggi.

Kegiatan literasi di sekolah ataupun di sebuah kampus akan berjalan dengan lancar dan optimal jika mendapatkan dukungan dari berbagai pihak di lingkungan tersebut, baik warga sekolah, ataupun warga kampus lainnya. Selain dukungan dari sumber daya manusianya, kegiatan literasi juga membutuhkan dukungan di luar hal itu yakni sebuah fasilitas yang dapat menopang kegiatan literasi, seperti adanya tempat yang dibuatkan khusus untuk tempat membaca, banyaknya buku yang disediakan oleh setiap instansi, serta selalu mengapresiasi seseorang yang bisa selesai dengan maksimal membaca sebuah buku.

Oleh karena itu literasi memberikan kontribusi yang sangat besar terhadap pengembangan Pendidikan kewarganegaraan di sekolah ataupun di kampus.

\section{DAFTAR PUSTAKA}

Aini, D. N. (2018). Pengaruh Budaya Literasi Dalam Mengembangkan Kecerdasan Kewarganegaraan. Biormatika Jumal Ilmiah FKIP Universitas Subang, 4(1), 1-10.

Arsani, N. K., et. all (2017). Pengaruh Model Pembelajaran SAVI Berbantuan Gerakan Literasi Sekolah Terhadap Hasil Belajar PKn Siswa Kelas IV. e-Journal PGSD Universitas Pendidikan Ganesha, 5(2).

Barnawi \& Arifin, (2016). Strategi \& Kebijakan Pembelajaran PENDIDIKAN KARAKTER. Jogjakarta: Ar-Ruzz Media.

\footnotetext{
Dan, B. (2017). 23 November 2017 PUSAT KURIKULUM DAN PERBUKUAN JAKARTA, 2017. November, 1-25.
}

Ginanjar, A., Putri, N. A., Nisa, A. S., Hermanto, F., \& Mewangi, A. B. (2019). Implementasi Literasi Digital Dalam Proses Pembelajaran Ips Di Smp Al-Azhar 29 Semarang. Harmony, 4(2), 99-105.

Hapsari, D. T. (2018). Masyarakat Indonesia. Jurnalisme Radio Pada Era Digital: Tranformasi Dan Tantangan, 44, 61-74.

Ihsan, H. Fuad. (2005). Dasar-Dasar Kependidikan. Jakarta: PT Rineka Cipta.

Maftuhin, Azis, A., \& Nugraha, D. M. (2021). Implementation of Digital Citizenship's Concept in Online Learning of Civic Education. 524(Icce 2020),

$1-8$. https://doi.org/10.2991/assehr.k.210204.0 01

Muhajang, T., \& Pangestika, M. D. (2018). Pengaruh Literasi Informasi Terhadap Efektivitas Belajar Siswa. Pedagonal : Jurnal Ilmiah Pendidikan, 2(2), 15-22. https://doi.org/10.33751/pedagog.v2i2.8 49

Pitman, S. D., \& Daniels, C. B. (2016). Quantifying ecological literacy in an adult western community: The development and application of a new assessment tool and community standard. PLoS ONE, 11(3), 119.

Rifai, A., Adha, M. M., Hartino, A. T., Ulpa, E. P., \& Supriyono, S. (2021). Pengembangan Literasi Digital Aplikasi Civication (Civic Application) Meningkatkan Civic Competence Siswa di Era Adaptasi Kebiasaan Baru. In A. Y. Kamlasi, F. Fadillah, I. Setiawan, K. Fajriatin, M. N. Salasa, \& T. Utami (Eds.), Prosiding Konferensi Nasional Kewarganegaraan $V$ (pp. 1-13). UNY Press. http://repository.1ppm.unila.ac.id/id/epri nt $/ 27617$

Septiyantono, Tri. 2016. Literasi Informasi. Tanggerang Selatan: Universitas Terbuka.

Suastra, I Wayan. (2009). Pembelajaran Sains Terkini”. Singaraja: Universitas Pendidikan Ganesha. 
Putri Aulia, dkk / Harmony 6 (1) (2021)

Suryatni, L. (2019). Pendidikan Kewarganegaraan dan Literasi Media Dalam Mencerdaskan Netizen di Media Sosial. Mitra Manajemen, 10(2), 79-90.

Wandasari, Y. (2017). Implementasi Gerakan Literasi Sekolah (Gls) Sebagai Pembentuk Pendidikan Berkarakter. JMKSP (Jurnal Manajemen, Kepemimpinan, Dan Supervisi Pendidikan), 2(2), 325-343. https://doi.org/10.31851/jmksp.v2i2.148 0

Warsihna, J. (2016). Meningkatkan Literasi Membaca Dan Menulis Dengan Teknologi Informasi Dan Komunikasi (Tik). Jurnal Kwangsan, $\quad 4(2), \quad 67$. https://doi.org/10.31800/iurnalkwangsan $\underline{\mathrm{v} 4 \mathrm{i} 2.84}$ 